\title{
Determination of Serum Copper and Zinc Level of Bangladeshi Breast Cancer Patients
}

\author{
Sanjida Afrin, M. Nuruzzaman Khan, Papia Haque and Mohammed Mizanur Rahman* \\ Department of Applied Chemistry and Chemical Engineering, Faculty of Engineering and Technology, \\ University of Dhaka, Dhaka-1000, Bangladesh.
}

\begin{abstract}
*Corresponding Author: Mohammed Mizanur Rahman, Department of Applied Chemistry and Chemical Engineering, Faculty of Engineering and Technology, University of Dhaka, Dhaka-1000, Bangladesh, Email: mizanur.rahman@du.ac.bd
\end{abstract}

\begin{abstract}
There are a number of possible risk factors for breast carcinoma. Changes in the serum level of some micronutrients like copper and zinc might have a role in the pathogenesis of breast cancer. In this study we have demonstrated the serum copper and zinc levels and their ratio between control healthy women and patients with advanced breast cancer (stage $I I I+I V)$ those were determined by atomic absorption spectroscopy (AAS). The 45 participants in this study were divided into two groups-control group consisted of 22 healthy controls and case group with 23 breast cancer patients respectively. There was a significant increase in mean $\mathrm{Cu}, \mathrm{Zn}$ and $\mathrm{Cu} / \mathrm{Zn}$ serum level $1.54 \pm 0.420,1.01 \pm 0.288$ and $1.67 \pm 0.719 \mathrm{mg} / \mathrm{L}$ respectively for cancer patients., In contrast, the serum copper, zinc and Cu/Zn level for the control group $(P<0.05)$ the healthy women were found significantly lower than cancer patients as $0.84 \pm 0.20,0.71 \pm 0.085$, and $1.15 \pm 0.283$ $m g / L$ respectively. In the present study, a relationship was seen between the level of trace elements and the occurrence of breast cancer, suggesting that the imbalance in copper and zinc concentration in blood serum may be associated to breast cancer of the Bangladeshi women.
\end{abstract}

Keywords:Atomic absorption spectroscopy; breast cancer; blood serum; copper; zinc.

\section{INTRODUCTION}

Breast cancer is a common disease and the second leading cause of death among women of the developed countries[1]. Breast cancer is an uncontrolled growth of breast cells. The risk of breast cancer is increasing worldwide day by day[2]. The number of women afflicted by breast cancer is on gradual rise in Bangladesh also. According to the findings from different government and non-government institutions, there are more than 1.2 million different types of cancer patients in Bangladesh. Annually, 0.2 million people are being added to the number of cancer cases. Although many studies have focused on breast cancer aetiology, nosogenesis and treatment, various aspects of this disease remain unknown. However, it is believed that trace elements play important roles in biological processes relevant to breast cancer, especially those elements that are essential components of antioxidants[3]. As an activator of many enzymes involved in the synthesis of DNA and RNA, zinc has been the subject of investigations regarding its importance in biochemical processes and antioxidant defense [4].
There are various risk factors for breast cancer. These include gender, age, estrogens, hormonal problems, diet, exercise, alcohol consumption, smoking, genetics, family history, taking hormone replacement therapy etc[5]. There are some micronutrients like copper and zinc which have a role in making the body enzymes and thus they may have a role in the pathologic processes of the human body[6]. The alteration of trace elements such as zinc and copper may have an influence in the activities of antioxidant enzymes as well. Some studies have shown that zinc can induce apoptosis in cancer cells and inhibit cell proliferation. High levels of zinc supplementation had a positive effect on reducing oxidative stress and improving immune responses in cancer patients[7]. However, some studies have indicated that zinc serves as a co-factor for cancer cell fission and replication[8] . Kuo et al, showed that the serum zinc levels in women with breast cancer were lower than those in healthy controls[9], and a similar result was reported for hair zinc levels[10]. Copper is an essential micronutrientand has an important role in metabolism. However, some remarkable 
statistical changes in the distribution of copper in patients with various neoplasms have been observed[11].

In recent years, serum micronutrient levels have been estimated in order to evaluate their possible role in the etiology of various kinds of carcinoma. Several studies[12, 13] have found differences in the copper and zinc level in blood serum for control and cancer patients. In this context, we wish to conduct a case-control study of the concentration of $\mathrm{Cu}$ and $\mathrm{Zn}$ in blood serum for the first time in Bangladesh. This study will estimate and compare blood serum level of $\mathrm{Cu}$ and $\mathrm{Zn}$ among healthy samples (control) and breast cancer patients.

\section{Materials ANd Methods}

\subsection{Patients and Sampling}

This cross sectional study was conducted on 23 female breast cancer patients registered at Ahsania Mission Cancer and General Hospital, Dhaka, Bangladesh and 22 healthy volunteer, with no report of cancer or any other systematic diseases. The study was conducted from January to December 2016 in Dhaka, Bangladesh and it was approved by the medical ethics committee for human study of Faculty of Medicine of the University of Dhaka, Bangladesh.

Biochemical measurements were done only for the patients who had been registered as patients with advanced breast cancer in the hospital after clinical, radiological (mammography) and histopathological diagnosis. Patients with diabetes mellitus, hypertension, jaundice, pregnant patients, patients who were breast feeding, taking hormonal therapy were excluded. The samples were collected from patients before starting chemotherapy, radiotherapy or any other treatment related to breast cancer. The control group consisted of 22 volunteers matched on age, sex and smoking status of the case group. The clinical features of the patients and control subjects are shown in table 1 .

Table1. Clinical features of controls and case subjects

\begin{tabular}{|l|l|l|}
\hline & \multicolumn{1}{|c|}{ Case } & Control \\
\hline Age(mean years \pm SD) & $47.8 \pm 9.42$ & $49.8 \pm 8.42$ \\
\hline Gender \% (n) & $0(0)$ & $0(0)$ \\
\hline Male & $100(23)$ & $100(22)$ \\
\hline Female & $0(0)$ & $0(0)$ \\
\hline Smoking \% (n) & $100(23)$ & $100(22)$ \\
\hline Smoker & $100(23)$ & $100(22)$ \\
\hline Non smoker
\end{tabular}

About $5 \mathrm{ml}$ of blood samples were drawn from the cubital vein and serum was separated by centrifugation at $1000 \mathrm{~g}$ for $10 \mathrm{~min}$. Sterile disposable syringes were used for sample collection. The blood samples from cancer patients were collected in Eppendrof and then transported in an icebox. The serum was separated immediately by centrifugation. All the serums were transferred to Eppendrofs and stored at $-20^{\circ} \mathrm{C}$ until analysis.

\subsection{Biochemical Measurements}

For analysis with Atomic Absorption Spectroscopy, Copper and Zinc standards (dissolved in $2 \%$ nitric acid) were purchased from Perkin Elmer, USA. Nitric acid was purchased from Sigma Aldrich, Germany. Deionized water was used for this purpose. The Analyst 800 AAS machine from USA was used for AAS analysis. A HST $250 \mathrm{VM}$ vortex from Korea and HTR 220E analytical balance from Japan were used in the research work. The model of centrifuge was Hettich, D-78532 and Hemocold refrigerator was used.

For preparation of standard solutions, the standard stock solutions of copper and zinc, trace elements were dissolved in $2 \% \mathrm{HNO}_{3}$ to a concentration of $1000 \mathrm{ppm}$. These were diluted with deionized water to the desired concentrations in separate $100 \mathrm{ml}$ volumetric flasks for calibration. Calibration curves for copper and zinc are given in fig 1 and fig 2 . For sample preparation, 150 microliter of serum was diluted to 1500 microliter with deionized water. At first, the nebulizer was rinsed by aspirating with water containing $1.5 \mathrm{~mL} \mathrm{HNO}_{3}$ per liter. The blank was atomized and set to the zero value. Samples were atomized and there absorbance were determined. Lamps were changed and the procedure was repeated for each element.

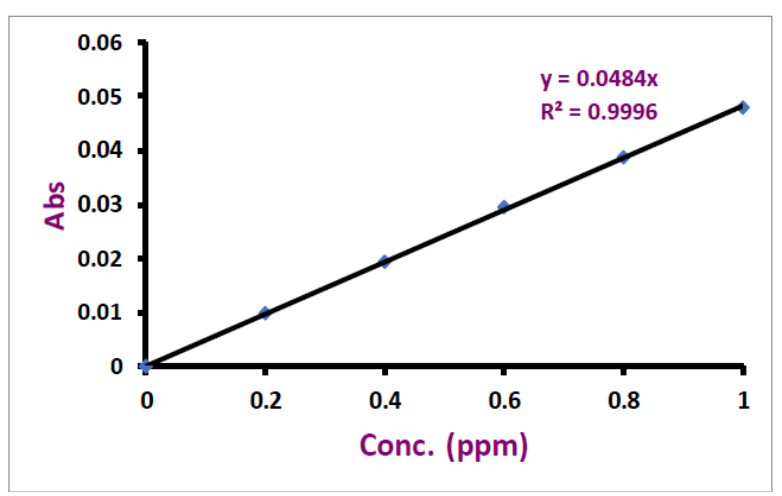

Fig 1: Calibration curve for Copper for Atomic Absorption Spectroscopy (AAS) analysis. 


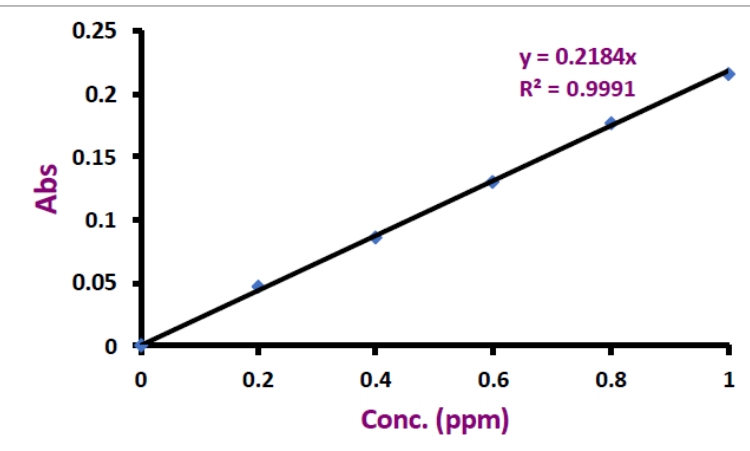

Fig 2:Calibration curve for Zinc for Atomic Absorption Spectroscopy (AAS) analysis.

\subsection{Statistical Analysis}

The concentrations of trace elements were expressed in ppm unit. The mean concentrations were expressed in mean \pm SD. The statistical analysis was done by Student's t- test. Significance level was set as $\mathrm{P}<0.05$.

\section{RESUltS AND DISCUSSION}

Serum levels of $\mathrm{Cu}, \mathrm{Zn}$ and their ratio were measured from 22 healthy female controls as well as 23 advanced breast cancer patients by AAS. The mean values of the concentration of $\mathrm{Cu}, \mathrm{Zn}$ and $\mathrm{Cu} / \mathrm{Zn}$ ratio belonging to controls and cancer serums have been summarized in Table 2. Serum $\mathrm{Cu}$ and $\mathrm{Zn}$ level were found significantly higher for cancer patients than control healthy women. Though serum $\mathrm{Cu} / \mathrm{Zn}$ ratio was higher in cases of controls, their relationship is insignificant as given in Table 2 .

Table2.Mean $\pm S D$ concentration of $\mathrm{Cu}$, Zn and their ratio in serums collected from case and control group

\begin{tabular}{|l|c|c|l|}
\hline & Case & Control & $P$-value \\
\hline $\mathrm{Cu}(\mathrm{mg} / \mathrm{L})$ & $1.54 \pm 0.420$ & $0.84 \pm 0.20$ & $<0.001^{*}$ \\
\hline $\mathrm{Zn}(\mathrm{mg} / \mathrm{L})$ & $1.01 \pm 0.288$ & $0.71 \pm 0.085$ & $<0.01^{*}$ \\
\hline $\mathrm{Cu} / \mathrm{Zn}$ & $1.67 \pm 0.719$ & $1.15 \pm 0.283$ & 0.065 \\
\hline
\end{tabular}

Comparisons were made using students t-test. $* P<0.05$, significant.

To our knowledge, this is the first ever study to examine the relationship between serum copper and zinc levels among Bangladeshi breast cancer patients. A sharp increase has been found for $\mathrm{Zn}$ and $\mathrm{Cu}$ levels as well as their ratio in case of patients than controls. However, $\mathrm{Cu}$ and $\mathrm{Zn}$ concentration has been found significantly and remarkably higher in case of cancer patients. Heavy metals and its compounds may interfere with breast cancer in different ways. They are not only an important risk factor for the development of breast cancer but also their cytotoxicity have beneficial effects inducing apoptosis and cytotoxicity in breast cancer cells. Thus it is important to understand, under which circumstances specifically cancer cells can be targeted by metals as well as their compounds[14]. The effect of $\mathrm{Cu}$ and $\mathrm{Zn}$ are discussed separately in the following section.

\section{Copper:}

Copper is an essential nutrient in human body. It plays important role in metabolism. However, copper generates reactive oxygen species via activation of several organic peroxides. These free radicals induce mutations by damaging the nucleic acid, DNA. Thus, an increase in serum levels of copper may have a role of compounding factor in case of breast cancer [15]. Like breast cancer, gynaecological cancer has also been found to be directly related to high concentration of copper in blood serum[16].The results of the present study demonstrated increased concentration of $\mathrm{Cu}$ for breast cancer patients which support the argument with many of the previous study reported in the literature[12, 13, 17].

\section{Zinc:}

Zinc is another trace element which is considered as a vital element for cellular growth. It is one of the micronutrients whose serum level changes are effective in oxidation and regeneration processes as well as development of carcinogenesis[18]. Zinc participates in the transcription process as a cofactor. Furthermore, it plays an active part in the enzymatic antioxidant system, including carbonic anhydrase, superoxide dismutase, and leucine aminopeptidase. These factors take part in homeostasis of body against the tumor progression[19]. Moreover, Zinc may be directly related to the prevention of DNA damage as well as gene mutation. Thus, zinc as an antioxidant decreases the risk of carcinoma[20]. The results of the concentration of zinc obtained in the serum of cancer patient were obtained significantly high than control that supports the findings in different report in the literature as mentioned above. In many of the previous study it has been demonstrated the causes of different tumors for increased $\mathrm{Zn}$ concentration.

The role of zinc in the synthesis of nucleic acid, its effects in producing metallothioneins, grabbing free radicals and its importance in the activity of cytotoxic $\mathrm{T}$ cells have made zinc a very important micronutrient for our body. 
However, animal studies reported that zinc may enhance tumor prognosis[21]. Furthermore, primary studies on human beings evaluate the role of zinc and other micronutrients in inducing treatment effects in patients with precancerous and cancerous lesions[22].

On the other hand, a large number of literature suggest that $\mathrm{Cu} / \mathrm{Zn}$ ratio can play a vital role for abnormal growth of tissue or tumor growth[23]. In the present study we have observed an increased level of $\mathrm{Cu} / \mathrm{Zn}$ ratio for breast cancer patients. However, the values are not significantly correlated with the control serums. This finding suggests that the $\mathrm{Cu} / \mathrm{Zn}$ level could not be used as a diagnostic biomarker of breast cancer. Additional studies are required to explore the association between serum $\mathrm{Cu} / \mathrm{Zn}$ level and severity of disease and to explore the usefulness of this marker as a prognostic factor after treatment of breast cancer

We also demonstrated the relationship between serum methylparaben concentration from cosmetic sources and breast cancer ${ }^{24}$. The result gave an insight for paraben exposure of Bangladeshi female breast cancer patients. The serum concentration of methylparaben was determined by using reverse phase high performance liquid chromatography (RPHPLC). The results of HPLC data demonstrated there is no existence of methylparaben in the control samples. There was only one sample from breast cancer patients, which had been found to contain traces of methylparaben. Though we are exposed to methylparaben extensively, very limited evidence has been found towards its relationship with breast cancer.

\section{CONCLUSiON}

The present study investigates the effect of copper and zinc in the pathogenesis of breast cancer. Our data is suggesting that there is a significant relationship of increased copper and zinc level in human blood serum with breast cancer. Though the $\mathrm{Cu} / \mathrm{Zn}$ ratio has also been found to increase in case of breast cancer patients, significant correlation has not been observed. It has been recommended that the imbalance of copper and zinc level in blood serum has an association with breast cancer. However, further prospective cohort studies concerning the causes of changes in copper, zinc concentration in blood serum of patients with breast cancer seems to be well ground for Bangladeshi women.

\section{ETHICAL APPROVAL}

All procedures performed in studies involving human participants were in accordance with the ethical standards of the national research committee and with the 1964 Helsinki declaration.

\section{ACKNOWLEDGEMENTS}

The authors are thankful to Dr. G. N. Nahar and H. N. Simol of the Centre for Advanced Research in Sciences (CARS), Bangladesh for providing laboratory facilities. The authors also would like to thank the Ahsania Mission Cancer and General Hospital, Dhaka, Bangladesh for their kind co-operation. S. A. would like to thank the National Ministry of Science and Technology, Bangladesh for providing fellowship.

\section{REFERENCES}

[1] Jemal A, Siegel R, Xu J, Ward E. Cancer statistics, 2010. CA: a cancer journal for clinicians. 2010;60:277-300.

[2] Baselga J, Gelmon KA, Verma S, Wardley A, Conte P, Miles D, Bianchi G, Cortes J, McNally VA, Ross GA. Phase II trial of pertuzumab and trastuzumab in patients with human epidermal growth factor receptor 2positive metastatic breast cancer that progressed during prior trastuzumab therapy. Journal of clinical oncology. 2010;28:1138-44.

[3] Federico A, Iodice P, Federico P, Del Rio A. Effects of selenium and zinc supplementation on nutritional status in patients with cancer of digestive tract. European journal of clinical nutrition. 2001;55:293.

[4] Chasapis CT, Loutsidou AC, Spiliopoulou CA, Stefanidou ME. Zinc and human health: an update. Archives of toxicology. 2012;86:52134.

[5] Carruba G. Estrogen and prostate cancer: An eclipsed truth in an androgen-dominated scenario. Journal of cellular biochemistry. 2007;102:899-911.

[6] Kasapović J, Pejić S, Todorović A, Stojiljković V, Pajović SB. Antioxidant status and lipid peroxidation in the blood of breast cancer patients of different ages. Cell biochemistry and function. 2008;26:723-30.

[7] Prasad AS. Zinc: role in immunity, oxidative stress and chronic inflammation. Current Opinion in Clinical Nutrition \& Metabolic Care. 2009; 12:646-52. 
[8] Wu X, Tang J, Xie M. Serum and hair zinc levels in breast cancer: a meta-analysis. Scientific reports. 2015;5:12249.

[9] Kuo HW, Chen SF, Wu CC, Chen DR, Lee JH. Serum and tissue trace elements in patients with breast cancer in Taiwan. Biological Trace Element Research. 2002;89:1-11.

[10] Wu H-DI, Chou S-Y, Chen D-R, Kuo H-W. Differentiation of serum levels of trace elements in normal and malignant breast patients. Biological trace element research. 2006;113:9-18.

[11] Yelinova V, Glazachev Y, Khramtsov V, Kudryashova L, Rykova V, Salganik R. Studies of human and rat blood under oxidative stress: changes in plasma thiol level, antioxidant enzyme activity, protein carbonyl content, and fluidity of erythrocyte membrane. Biochemical and biophysical research communications. 1996;221:300-3.

[12] Ajayi G. Copper and zinc concentrations in Nigerian women with breast cancer. European journal of gynaecological oncology. 2011;32:307.

[13] Zarghami N, Asadi J, Mahbob S, Mohammadzadeh G, Mohajeri A. Serum Levels of $\mathrm{Se}, \mathrm{Zn}, \mathrm{Cu}$ and $\mathrm{Cu} / \mathrm{Zn}$ Ratio in Iranian Breast Cancer Patients. Pharmaceutical Sciences, Spring. 2008:27-32.

[14] Daniel KG, Chen D, Orlu S, Cui QC, Miller FR, Dou QP. Clioquinol and pyrrolidinedithiocarbamate complex with copper to form proteasome inhibitors and apoptosis inducers in human breast cancer cells. Breast Cancer Research. 2005;7:R897.

[15] Chan A, Wong F, Arumanayagam M. Serum ultrafiltrable copper, total copper and caeruloplasmin concentrations in gynaecological carcinomas. Annals of clinical biochemistry. 1993;30:545-9.
[16] Filomeni G, Cerchiaro G, Ferreira AMDC, De Martino A, Pedersen JZ, Rotilio G, Ciriolo MR. Pro-apoptotic activity of novel Isatin-Schiff base copper (II) complexes depends on oxidative stress induction and organelleselective damage. Journal of Biological Chemistry. 2007;282:12010-21.

[17] Huang Y-L, Sheu J-Y, Lin T-H. Association between oxidative stress and changes of trace elements in patients with breast cancer. Clinical biochemistry. 1999;32:131-6.

[18] Pavithra V, Sathisha T, Kasturi K, Mallika DS, Amos SJ, Ragunatha S. Serum levels of metal ions in female patients with breast cancer. Journal of clinical and diagnostic research: JCDR. 2015;9:BC25.

[19] Mazdak H, Yazdkhasty F, Mirkhesht N, Shafieyan M, Behzad E. Serum Iron, Copper, Zinc levels in bladder cancer patients in comparison with healthy individuals. Research in Medicine. 2010;34:56-60.

[20] Carvalho AL, Sanz L, Barettino D, Romero A, Calvete JJ, Romao MJ. Crystal structure of a prostate kallikrein isolated from stallion seminal plasma: a homologue of human PSA. Journal of molecular biology. 2002;322:325-37.

[21] Prasad AS. Impact of the discovery of human zinc deficiency on health. Journal of the American College of Nutrition. 2009;28:25765.

[22] Doerr TD, Marks SC, Shamsa FH, Mathog RH, Prasad AS. Effects of zinc and nutritional status on clinical outcomes in head and neck cancer. Nutrition. 1998;14:489-95.

[23] Zhai H, Chen X, Hu Z. Study on the relationship between intake of trace elements and breast cancer mortality with chemometric methods. Computational biology and chemistry. 2003;27:581-6.

Citation: Sanjida Afrin, M. Nuruzzaman Khan, PapiaHaque and Mohammed Mizanur Rahman. Determination of Serum Copper and Zinc Level of Bangladeshi Breast Cancer Patients. ARC Journal of Cancer Science 2018; 4(2):7-11. DOI: http://dx.doi.org/10.20431/2455-6009.0402002

Copyright: (C) 2018 Authors. This is an open-access article distributed under the terms of the Creative Commons Attribution License, which permits unrestricted use, distribution, and reproduction in any medium, provided the original author and source are credited. 